\title{
トンネル窯におけるさやの熱破壊傾向
}

\author{
稲垣甲子郎・坂 部 隆 夫 \\ (愛知県工業指導所)
}

\section{Thermal Fracture of Saggers in the Tunnel Kiln}

\author{
By \\ Kineo INAGAKI and Takao SAKABE \\ (Industrial Research Institute, Aichi Prefecture, Nagoya)
}

\begin{abstract}
In order to improve the life of saggers, three kinds of material were studied as for the sagger bodies. The physical properties of trial manufactured saggers, thermal stress for saggers of large size, and temperature gradients between the outer and inner sides of saggers in the tunnel kiln were examined. The mechanical strengths, thermal expansion, specific heat, and thermal conductivity of saggers of chamotte, cordierite, or semi silicon carbide type were measured.

The suitable heating or cooling rate for saggers were found to be $1.5^{\circ} \mathrm{C} / \mathrm{min}$ for chamotte type, and $6^{\circ} \mathrm{C} / \mathrm{min}$ for cordierite or semi silicon carbide type saggers, from thermal stress analysis.

[Received July 30, 1968]
\end{abstract}

\section{1. 緒言}

陶磁器の製造原価に大きな比重を占めるさや（匣鉢） の耐久性を向上させることは急務である.ささや熱的, 機械的に充分耐えることが必要であり，安価でなければ ならない。

従来から，熱衝撃の激しい場所での使用中における急 熱急冷による破壞現象 ${ }^{1)}$ および最大許容温度差 ${ }^{2}$ の決定 などについては多数の研究が認められるが，トンネル塞 内における条件での材料の熱破壊を予知する研究は少な く，唫かに高津 ${ }^{3)}$ らの報告がみられるのみで，この条件 での窯業品の加熱, 冷却速度の決定とか, 耐火材料の選 定方法は経験的な結果をもとにしている場合が多い.

したがって，あらかじめさや中に発生する熱応力分布 とか，それぞれのさや材質に応じた安全な加熱，冷却速 度を求めることができれば，陶磁器生産上経済的に有益 である。

本報告では, まず某社の食器製造用トンネル窯内の温 度上昇, 降下速度と窯内で使用中におけるさやの内外面 温度差とをしらべ，実用に供して比較的耐久性がよく， またよく普及した $30 \mathrm{~cm}$ 肉血用コーディエライト質, 半炭化珪素質さやが，トンネル宰内で使用されたとさに さやに生ずる温度勾配と熱応力とを計算によって求め， それぞれの材質のさやが破壊しないような最大の加熱ま たは冷却速度について検討した. 同時に, 比較のためシ ヤモット質についても試みた。

\section{2. さや素地の物理性質}

さや素地の基本調合 ${ }^{4)}$ は既に報じたが，ここで用いた 調合を表-1 に示す.

表において炭化珪素は $\mathrm{S}$ 社製黒色を用い，コーディエ ライト質骨材の調整方法は朝鮮カオリン 3 , 枝下木節 1 の重量比の混合物に水酸化マグネシウムを外枠へ $16 \%$ 加えたもの定トンネル葖で SK 13 に焼成した. ここで 炍焼ボーキサイト粉末を加えたのは, 使用中における底 下がり防止の役目である。この素地のX線回折結果はコ 一ディエライトが主体で, ムライト,スピネルも認めら れる。

Table 1. Mixing rate of raw materials.

1) Semi $\mathrm{SiC}$ sagger body

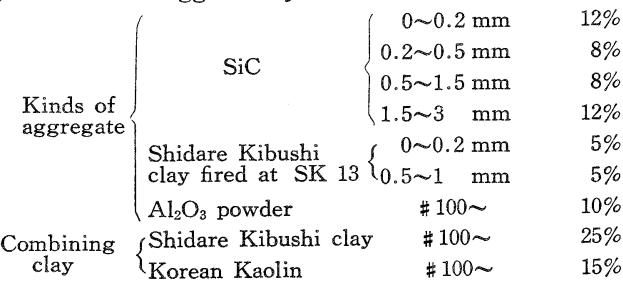

2) Cordierite sagger body

\begin{tabular}{|c|c|c|c|}
\hline & & & \\
\hline \multirow{4}{*}{$\begin{array}{l}\text { Grain of } \\
\text { cordierite } \\
\text { aggregate }\end{array}$} & $0 \sim 0.3 \mathrm{~mm}$ & & $15 \%$ \\
\hline & $0.3 \sim 0.8 \mathrm{~mm}$ & & $7 \%$ \\
\hline & $0.8 \sim 2 \mathrm{~mm}$ & & $10 \%$ \\
\hline & $2 \sim 5 \quad \mathrm{~mm}$ & & $23 \%$ \\
\hline \multirow{3}{*}{$\begin{array}{l}\text { Combining } \\
\text { clay }\end{array}$} & Shidare Kibushi clay & $\# 100 \sim$ & $25 \%$ \\
\hline & Korean Kaolin & $\# 100 \sim$ & $10 \%$ \\
\hline & Bauxite & $\# 100 \sim$ & $7 \%$ \\
\hline Adition & $\{$ Magnesium hydroxide & $\# 220 \sim$ & $3 \%$ \\
\hline
\end{tabular}

成形条件は，15\% の成形水量と $1 \mathrm{t} / \mathrm{cm}^{2}$ 圧でそれぞ れの物理試験に適した寸法に成形し，トンネル窯で SK 
Table 2. Physical properties of sagger body fired at SK 13.

\begin{tabular}{lccc}
\hline & $\begin{array}{c}\text { Semi SiC } \\
\text { type }\end{array}$ & $\begin{array}{c}\text { Cordierite } \\
\text { type }\end{array}$ & $\begin{array}{c}\text { Chamotte } \\
\text { type }\end{array}$ \\
\hline Compressive strength $\left(\mathrm{kg} / \mathrm{cm}^{2}\right)$ & 486 & 394 & 175 \\
Modulus of rupture $\left(\mathrm{kg} / \mathrm{cm}^{2}\right)$ & 180 & 150 & 50 \\
$\begin{array}{l}\text { Coefficient of thermal } \\
\text { expansion at } 900^{\circ} \mathrm{C}(\%)\end{array}$ & 0.25 & 0.33 & 0.75 \\
Young's modulus $\left(\mathrm{kg} / \mathrm{cm}^{2}\right)$ & $7.7 \times 10^{4}$ & $9.0 \times 10^{4}$ & $7.0 \times 10^{4}$ \\
Thermal conductivity & $13 \times 10^{-4}$ & $15 \times 10^{-4}$ & $2.52 \times 10^{3}$ \\
$\left(\mathrm{cal} / \mathrm{cm}^{2} \cdot{ }^{\circ} \mathrm{C} \cdot \mathrm{sec}\right)$ & 0.19 & 0.18 & 0.23 \\
Specific heat $(\mathrm{kcal} / \mathrm{kg})$ & 2.5 & 2.0 & 2.0 \\
\hline Bulk specific gravity & & & \\
\hline
\end{tabular}

13 に 2 日間かけて焼成した。本実験で測定した物理試 験項目とその結果は表-2 に示すが，このために使用し た装置と方法は既報5)のとおりである.

表には，市販のシャモット質さやで比較的耐久性のよ いものをそれぞれの物理試験用に切り出して測定した結 果も参考として示す.

\section{3. 食器焼成用トンネル窯内における シャモット質さやの温度分布}

さやの熱破壊条件を求める目的で, 某社の食器焼成用 トンネル窯を用いて，図-1 に示す位置に台車方向から 熱電対を差し込み電子式自動平衡温度計を用いて温度を 測定した. これに用いたさやは $30 \mathrm{~cm}$ 食皿用のもので外 径 $34 \mathrm{~cm}$, 側面の肉厚 $1.5 \mathrm{~cm}$, 底の厚さは薄いところで $0.7 \mathrm{~cm}$ である。図-2 には台車上に積み重ねた一たての 中央部のさや内の温度上昇と降下速度を調べた結果を示 す.また，さやの中に火にあたる側とその反対側（図-3 における×印）に熱電対をたて，焼成時におけるさやの 外側と内部の温度差を測定した結果を図-3に示す. 図一 2 から, 騺の予熱部ではさや内の温度上昇速度は最高 $4^{\circ} \mathrm{C} / \mathrm{min}$ であり, また冷却速度は最高 $3^{\circ} \mathrm{C} / \mathrm{min}$ で普通 $2^{\circ} \mathrm{C} / \mathrm{min}$ である.図-3から,さやの内側と外側とでは䔂 の予熱部で最大 $120^{\circ} \mathrm{C}$ の温度差を示し, 泠却帯では最大 $90^{\circ} \mathrm{C}$ の温度差で，いずれも $400^{\circ} \mathrm{C}$ 附近が一番大きい.

\section{4. さやの温度分布式}

加熱および冷却が一定速度でおこなわれる場合におけ るさやの温度分布は半無限固体の熱伝導方程式 ${ }^{6)}$ を解く ことによって表わされる.すなわち, 温度 (u) は $x$ の みの関数であるとし, 初めの温度を $0^{\circ} \mathrm{C}$ とすると (1) 式の微分で与えられる.

$$
\frac{\partial u}{\partial t}=k \frac{\partial^{2} u}{\partial x^{2}}
$$

ただし， $k$ : 温度扡散率 $\quad t$ : 時間 $\quad x$ : 方向

$u$ :ある地点における温度

(1) 式を $(u)_{t=0}=0$

$$
\left.\begin{array}{l}
(u)_{t=0}=0 \\
(u)_{x=0}=n t \\
(u)_{x=\infty}=0
\end{array}\right\} \begin{aligned}
& \text { の初期条件で解くと (2) 式 } \\
& \text { で示される. }
\end{aligned}
$$
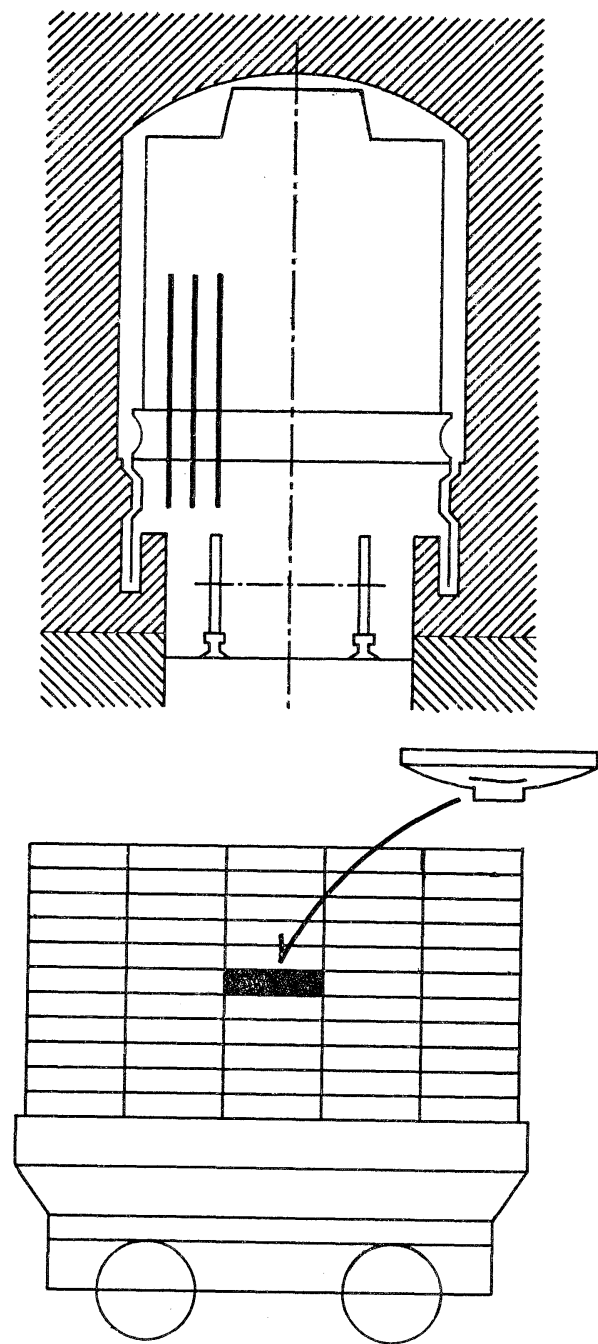

Fig. 1. Position of the thermocouple fixed on the carriage in the tunnel kiln.

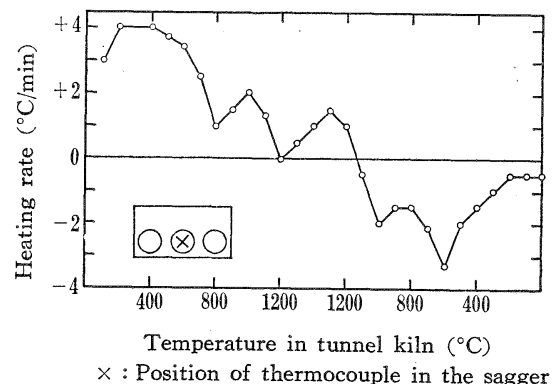

Fig. 2. Heating curve of the sagger in tunnel kiln.

$$
\begin{aligned}
u= & n\left[\left(t-\frac{x}{2 k^{2}}\right)\left(1-\frac{2}{\sqrt{\pi}} \int_{0}^{\frac{x}{2 k} \sqrt{t}} e^{-\beta 2} d \beta\right)\right. \\
& \left.-\frac{x \sqrt{t}}{k \sqrt{\pi}} e^{-\frac{x^{2}}{4 k 2 t}}\right] \ldots \ldots \ldots \ldots \ldots \ldots \ldots \ldots \ldots
\end{aligned}
$$

また $k^{2}=\sqrt{\frac{\lambda^{2}}{C_{p} \cdot \rho}}$ である。

ここで $\lambda$ : 熱伝導率 $C_{p}$ : 比熱 $\rho$ : 密度 


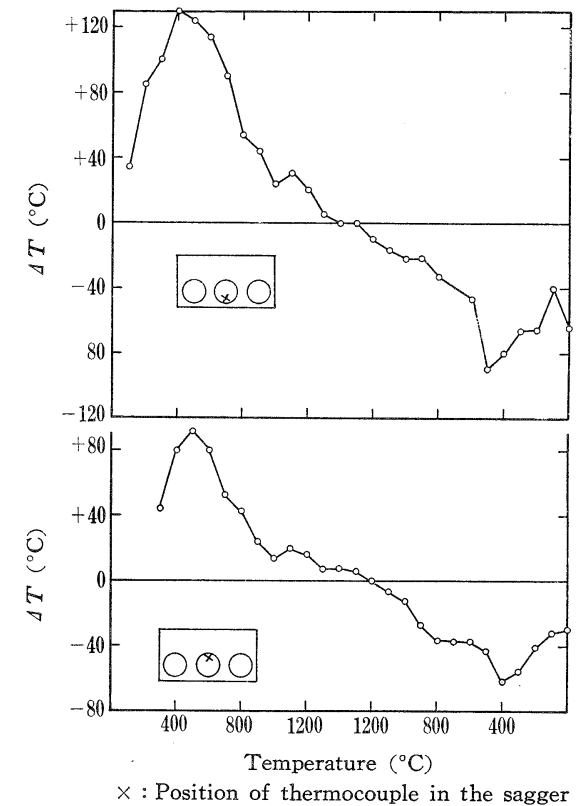

Fig. 3. Temperature difference between the tunnel kiln and the sagger.

\section{$n:$ 距離}

（2）式において，表-2 に示したさやの物理性質を代 入し, それぞれのさや素地の $3^{\circ} \mathrm{C} / \mathrm{min}$ 当りの加熱速度 における経過時間 $(h)$ に対する温度分布を計算した結 果を図-4 に示す. 図-4 はさやの壁の厚みは厚いもので も $2 \mathrm{~cm}$ 以下であるために, この距離まで求めた。 ま た，図はそれぞれの時間経過後では，熱はさや内部へ流 れるので，一般にはさや内部の空気への伝熱を考えに入 れる必要があり, 各温度分布曲線は厳密なものではな い. 図の温度分布曲線淔線的であり, コーディエライ 卜質,半炭化珪素質,シャモッ卜質の順序で $x=0$ と $x=$

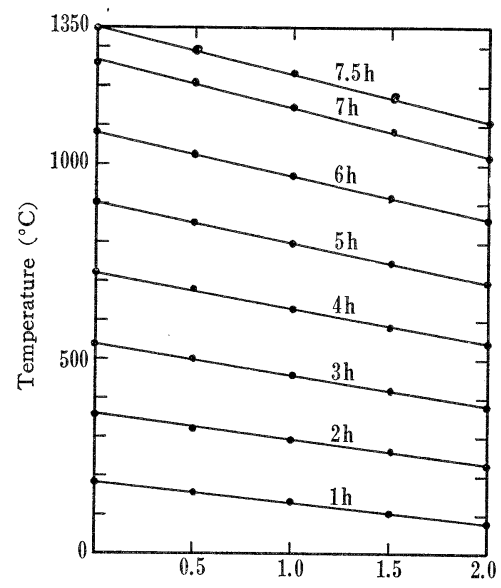

Distance from outer face in $\mathrm{cm}$

Fig. 4. (1) The variation of temperature gradients in the condierite body at heating rate of $3^{\circ} \mathrm{C} / \mathrm{min}$ : In the sagger body of $30 \mathrm{~cm}$ in diameter, and wall thickness of $2 \mathrm{~cm}$.

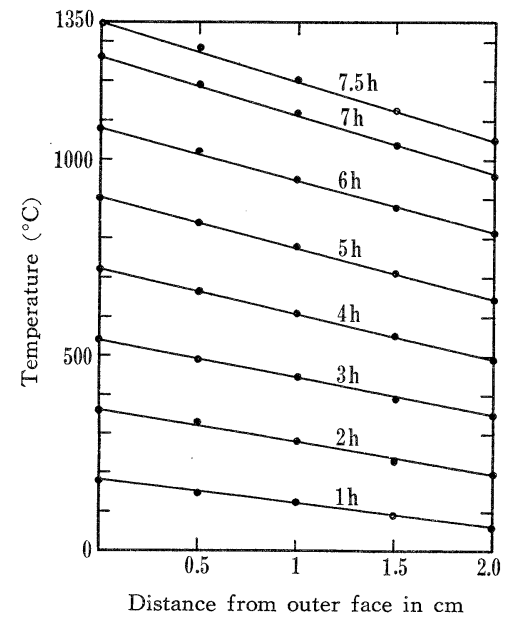

Fig. 4. (2) The variation of temperature gradients in the Semi-SiC body at heating rate of $3^{\circ} \mathrm{C} / \mathrm{min}$ : In the sagger body of $30 \mathrm{~cm}$ in diameter, and wall thickness of $2 \mathrm{~cm}$.

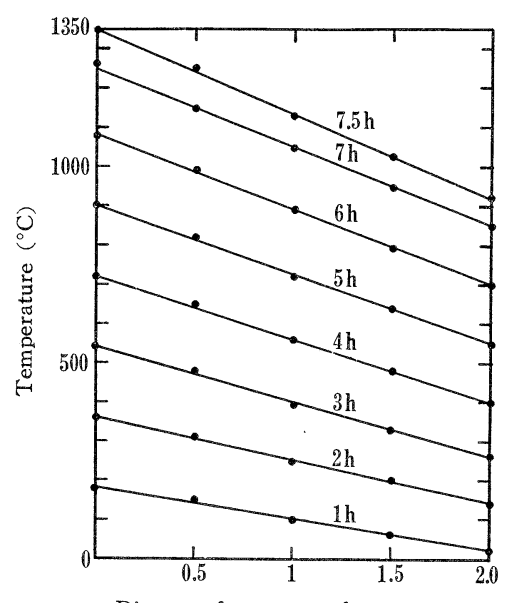

Distance from outer face in $\mathrm{cm}$

Fig. 4. (3) The variation of temperature gradients in the chamotte body at heating rate of $3^{\circ} \mathrm{C} / \mathrm{min}$ : In the sagger body of $30 \mathrm{~cm}$ in diameter, wall thickness of $2 \mathrm{~cm}$.

$2 \mathrm{~cm}$ 間の温度差が大きい. $3^{\circ} \mathrm{C} / \mathrm{min}$ の一定速度におけ る冷却の場合も同じである。

次に, タイルなど一度焼き用のさや形状では, さやの ふちに生地からの水蒸気を逃がす溝などをつけることが ある．このような形状で，側壁が薄いものではさやの内 側と外側とが同じ温度であると仮定すると熱伝導方程式 を $a$ の厚みの板において両面の温度変化が等しいとした 解.

$$
\begin{aligned}
& (u)_{x=0}=F(t) \\
& (u)_{x=a}=F(t) \\
& (u)_{t=0}=f(x)
\end{aligned}
$$

の条件で解いた式 (3) で表わされる.

$$
u=\frac{2}{a} \sum_{s=1}^{\infty}\left\{e^{-\frac{k 2 s^{2} \pi^{2}}{a^{2}}} t \cdot \sin \frac{s \pi x}{a} \int_{0}^{a} f(\lambda) \sin \frac{s \pi \lambda}{a} d \lambda\right.
$$


27

$$
\left.+\frac{k^{2} s \pi}{a} \int_{0}^{t} e^{-\frac{k^{2} s^{2} \pi^{2}}{a^{2}}}(t-\lambda) \cdot\left(F(\lambda)-F(\lambda)(-1)^{s}\right) d \lambda\right\}
$$

ただし, $s:$ 整数

この式で第 2 項は表面からの距離 $x$ に無関係である. いま，第 1 項にシャモット質の物理測定值を代入すると $e^{-\frac{k 2 s^{2} \pi^{2}}{a^{2}}} t$ の值は $s=1, t=50$ 秒で $1 / e^{5}$ となり, 50 秒 以上経過した場合では $u$ は表面温度の時間的変化に等 しいことになる. その結果として $3^{\circ} \mathrm{C} / \mathrm{min}$ の温度変化 では, さやの側壁とさや素地の中央とでは $2.5^{\circ} \mathrm{C} / \mathrm{min}$ の差しか生じないことがわかる。

\section{5. さやを急冷した際の温度分布}

トンネル宰において, $1200^{\circ} \sim 1400^{\circ} \mathrm{C}$ の焼成温度に保 持されたさやは，経済的問題その他から $800^{\circ} \sim 700^{\circ} \mathrm{C}$ 附近まで急冷されることがある。

この条件での温度分布を調べる目的で, 半無限固体に おける熱伝導方程式を次の条件で解く.（4）式で表わさ れる。

$$
\begin{aligned}
& \left.\begin{array}{l}
(u)_{x=0}=u_{0} \\
(u)_{t=\infty}=u_{0} \\
(u)_{t=0}=u^{\prime}
\end{array}\right\} \text { の条件 } \\
& u=u_{0}+\frac{2}{\sqrt{\pi}}\left(u^{\prime}-u_{0}\right) \int_{0}^{\frac{x}{2 k \sqrt{t}}} e^{-\beta^{2}} d \beta
\end{aligned}
$$

(4) 式において, $1000^{\circ} \mathrm{C}$ 以下の低温度ではさやの側 壁を管とみなしてその管外強制対流伝熱を考慮する必要 がある。これについては一応トンネル突冷却帯の炉壁の 泠却穴から泠たい空気の流れがさやに対して直角におか れたときすなわち単一円管の外面の伝熱式を適用する とヌセルト数 $N_{u}=h D / k_{f}$ とレイノルズ数 $R_{e}=u D / V_{f}$ との間には, $5 \times 10^{4}>R_{e}>10^{3}$ の範囲で $N_{u}=0.26 R_{e}^{0.6}$ $P_{r}{ }^{0.3}$ の実験式がある.ただし， $P_{r}=C_{p} \cdot u_{f} / k_{f}$ で与えら れる。

ここで, $C_{p}, u_{f}$ はそれぞれの流体の定圧比熱と粘度 である。

\section{$N_{u}$ : ヌセルト数 $h$ : 境膜伝熱係数 $D$ : 管外径 $k_{f}:$ 流体の熱伝導度 $\quad u_{0}:$ 遠方の流速 $V_{f}: \frac{t_{w}+t_{0}}{2}$ における運動粘度}

$t_{w}$ : 壁 (管表面) の温度 $t_{0}$ : 遠方の流体温度 本研究では, $D=30 \mathrm{~cm} \phi, u_{0}=500 \mathrm{~cm}, V_{f}=1.665$ $\left(\mathrm{cm}^{2} / \mathrm{sec}\right)$ とすると

$$
\begin{aligned}
& k_{f}=1.8 \times 10^{-4}\left(\mathrm{cal} / \mathrm{sec} \cdot \mathrm{cm} \cdot{ }^{\circ} \mathrm{C}\right) \\
& R_{e}=9063 \\
& P_{r}=1.667 \\
& N_{u}=71.76
\end{aligned}
$$

故に $h=4.305 \times 10^{-4} \mathrm{cal} / \mathrm{sec} \cdot \mathrm{cm}^{2} \cdot{ }^{\circ} \mathrm{C}$ となる.

この $h$ の值がさやの温度分布に与える影響について 検討してみる. 境膜の厚さ $\delta$ は $\delta=\lambda / h$ で与えられる.
窯業協会誌 $77[1] 1969$

21

ただし， $\lambda=k_{f}\left(\left(t_{w}+t_{0}\right) / 2\right) \quad \delta=0.42 \mathrm{~cm}$

この境膜を (4) 式に代入すると, 二, 三の経過時間後の

（4）式中の $\int_{0}^{\frac{x}{2 k \sqrt{t}}} e^{-\beta^{2}} d \beta$ 項は表-3の值となる.した がって $0.42 \mathrm{~cm}$ のところでは，1秒以上の経過時間で $\left(u^{\prime}-u_{0}\right)$ の $9 \%$ 以下しか温度変化がない。この境膜と 輻射放熱を無視してさやが急冷された際の温度分布を求 めた結果が図 -5 である. 図-5 から，急冷時において $2 \mathrm{~cm}$ 厚さのさや側壁で, 半炭化珪素質, コーディエラ イト質では 128 秒, シャモット質では 256 秒経過後で Table 3. Value of $\int_{0}^{\frac{x}{2 k \sqrt{ } t}} e^{-\beta 2} d \beta$ term.

\begin{tabular}{cl}
\hline Lapse of time & $\int_{0}^{\frac{x}{2 k \sqrt{t}} e^{-\beta 2} d \beta}$ \\
\hline 1 & 0.085 \\
2 & 0.056 \\
3 & 0.04 \\
\hline
\end{tabular}

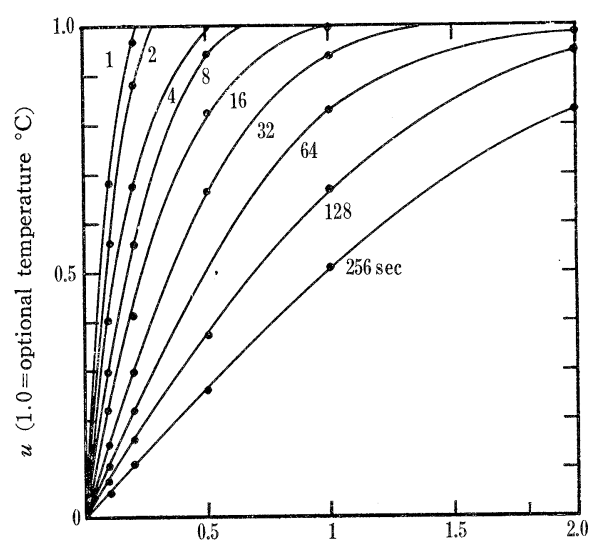

Distance from outer face in $\mathrm{cm}$

Fig. 5. (1) The variation of temperature gradients in the body of cordierite when cooled rapidly.

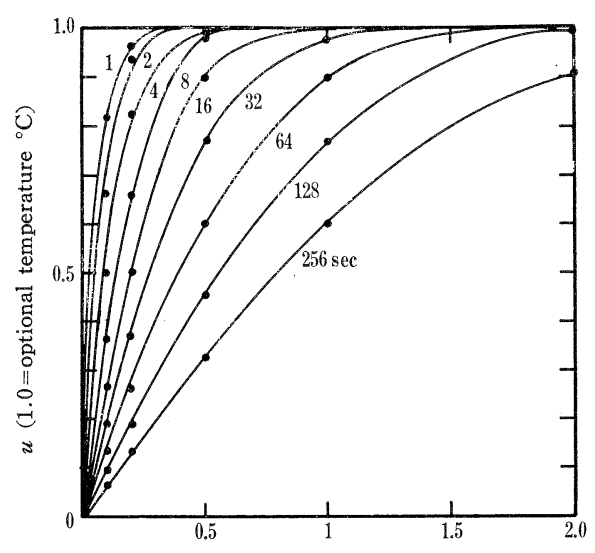

Distance from outer face in $\mathrm{cm}$

Fig. 5. (2) The variation of temperature gradients in the body of Semi-SiC when cooled rapidly. 


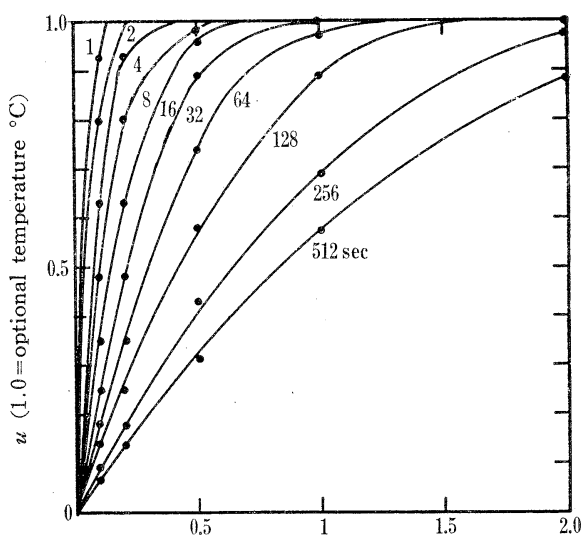

Distance from outer face in $\mathrm{cm}$

Fig. 5. (3) The variation of temperature gradients in the body of chamotte when cooled rapidly.

はさやの内面と外面との温度差がなくなり，さや内部の 空気の伝熱を考慮しなければならないので，各曲線は厳 密なものではない，乙かし，後述のように熱応力の最高 が表われるのはさや内部の空気に伝達する直前であるの で，あまり時閒が経過したときの温度差についてはくわ しく吟味の必要もないので略した。

\section{6.さや素地の内部に発生する熱応力}

内径 $a$, 外径 $b$ の筒状素地内に温度の不等分布が生 ずる場合に発生する熱応力は内外圧をうける場合と同様 に半径, 切線, 軸の 3 方向の主応力であり, この応力は 次式で表わされる。

中空円筒の熱応力（無限円筒）：

半径 $\sigma_{r}=\frac{E}{1-\mu} \cdot \frac{1}{r^{2}} \cdot\left\{\frac{r^{2}-a^{2}}{b^{2}-a^{2}} \int_{a}^{b} \alpha \theta r d r-\int_{a}^{r} \alpha \theta r d r\right\}$

切線 $\sigma_{\phi}=\frac{E}{1-\mu} \cdot \frac{1}{r^{2}} \cdot\left\{\frac{r^{2}+a^{2}}{b^{2}-a^{2}} \int_{a}^{b} \alpha \theta r d r\right.$

$$
\left.-\int_{a}^{r} \alpha \theta r-\alpha \theta r^{2}\right\}
$$

軸 $\sigma_{z}=\frac{E}{1-\mu} \cdot\left\{\frac{2}{b^{2}-a^{2}} \int_{a}^{b} \alpha \theta p r d r-\alpha \theta\right\}$

$$
E: \text { ヤング率 } \mu: \text { ポアソン比 }
$$

$\alpha:$ 円筒の任意半径 $b$ : 円筒の外径

$a:$ 円筒の内径 $r$ : 中心からの任意距離

$R$ : 円板半径 $\theta$ : 温度 (時間, 距離の関数)

この 3 熱応力のうち, 半径応力 $\sigma_{r}$ は円筒の内外面で 0 , 切線と軸の両応力 $\sigma_{\phi}, \sigma_{z}$ は内外面で最大值をとり, 同じ值である.したがって，さやの急熱急冷による亀裂 など，破壊に関与する主たる応力である切線応力のみを 取りあげる．また，さや底部の熱応力，すなわち円板熱 応力は

$$
\sigma_{\phi_{1}}=\alpha E\left(-\theta+\frac{1}{R^{2}} \int_{0}^{R} \theta r d r+\frac{1}{r^{2}} \int_{0}^{r} \theta r d r\right) .
$$

さきにえた温度分布を上式に代入して熱応力を求める にあたっては，耐火物においても弾性と熱間塑性の両性 質をもっている.すなわち，塑性域ではさやは温度不等 分布による歪を発生することが少ないので熱㐫力の発生 は弾性域のみを考えればよいことになる。そうして弾性 々熱間塑性の両域間の臨界温度については， Roberts， Booze ら多数の報告" があり，一般には $540^{\circ} \mathrm{C}$ 附近で 弾性を失うと言われている。したがって，この臨界温度 以上では応力の発生がないとした。

熱間塑性を加味した応力式は上記の式を変形して次の ようになる。すなわち，トンネル筀内の温度上昇過程で は, さや外側の面から $600^{\circ} \mathrm{C}$ の塑性域下限までの距離 をyとすると, さや側壁では内外両面からの場合を問題 にしなければならないが，底円板では外面から半径方向 の中心に向う場合しかないために（4)，(5) 式は次のよ うになる。

$r$ に $b-y-x, b$ に $b-y, a$ に $a+y$ を入れる.

ただし， $x$ : 表面からの任意距離

予熱帯では

$$
\begin{aligned}
\sigma_{\phi^{\prime}}= & \frac{E \alpha}{1-\mu} \cdot \frac{1}{(b-y-x)^{2}}\left\{\frac{(b-y-x)^{2}+(a+y)^{2}}{(b-y)^{2}-(a+y)^{2}}\right. \\
& \int_{b-a-2 y}^{0} \theta(x+y-b) d x \\
& \left.+\int_{b-a-2 y}^{x} \theta(x+y-b) d x-\theta(b-y-x)^{2} d x\right\} \\
\sigma^{\prime}{ }_{\phi 1}= & 2 E\left\{-\theta+\frac{1}{(R-y)^{2}} \int_{R-y}^{0}(x+y-R) d x\right. \\
& \left.+\frac{1}{(R-y-x)^{2}} \cdot \int_{R-y}^{x} \theta(x+y-R) d x\right\} \cdots(5) \ldots \ldots \ldots \ldots \ldots \ldots \ldots \ldots \ldots \ldots
\end{aligned}
$$

また，冷却帯において，円筒部 (さや側壁)では $2 つ$ の同心円柱が存在し, 各場合について (4) 式に $r=b$ $-x, a=b-y$ を入れる.

$$
\begin{aligned}
& \sigma_{\phi}^{\prime \prime}= \frac{E}{1-\mu} \cdot \frac{\alpha}{(b-x)^{2}}\left\{\frac{(b-x)^{2}+a^{2}}{b^{2}-(b-y)^{2}} \int_{y}^{0} \theta(x-b) d x\right. \\
&\left.+\int_{y}^{x} \theta(x-b) d x-\theta(b-x)^{2} d x\right\} \quad \cdots \cdots \cdots\left(4^{\prime \prime}\right) \\
& \sigma_{\phi 1}^{\prime \prime}= \frac{E \cdot \alpha}{(1-\mu)(b+y-x)^{2}}\left\{\frac{(b+y-x)^{2}+a^{2}}{(a+y)^{2}-a^{2}}\right. \\
& \int_{b+y-a}^{0} \theta(x-b-y) d x \\
&\left.+\int_{b+y-a}^{x} \theta(x-b-y) d x-\theta(b+y-x)^{2} d x\right\} \cdots\left(4^{\prime \prime \prime}\right)
\end{aligned}
$$

さやの底の部分では， $R$ と $R-y$ との間には円柱で あり，円板式が適用できず， $\left(4^{\prime \prime \prime}\right)$ 式が用いられる。 (5) 式に $R=a+Y$ を代入する. $Y: a$ から $600^{\circ} \mathrm{C}$ の 臨界温度までの距離。

$$
\begin{aligned}
\sigma_{\phi_{2}}^{\prime \prime}= & \alpha E\left\{-\theta+\frac{1}{(a+Y)^{2}} \int_{a+Y}^{0} \theta(-a-Y+x) a x\right. \\
& \left.+\frac{1}{(a+Y-x)^{2}} \int_{a+Y}^{x} \theta(x-a-Y) d x\right\} \cdots\left(5^{\prime \prime \prime}\right)
\end{aligned}
$$


上記の熱応力式にしたがって，それぞれのさやのトン ネル葖内での使用にともなら応力分布の計算をした結果 を，予熱带と泠却部分とに分けて検討する.

\section{1 温度上昇時における熱応力分布}

それぞれのさやの熱応力分布を側壁 (円筒部) と底 （円板）部分とに分けて図-6 と 7 亿示す. この図と表2 とから, $4^{\circ} \mathrm{C} / \mathrm{min}$ の昇温速度条件では半炭化珪素質, コーディエライト質さやでは熱応力よりも機械強度が大 きいことから推定して熱的破壊は抢こらないであらう。 しかし、シャモット質さやでは底部は亀裂を抏こさない であろらが，側壁では加熱 2 時間後 $\left(480^{\circ} \mathrm{C}\right)$ のとき, ひび割れする恐れがある。このひび割れの時期は $240^{\circ} \mathrm{C}$ ( 1 時間後) から $600^{\circ} \mathrm{C}$ (2.5 時間後) の閒であり，そ

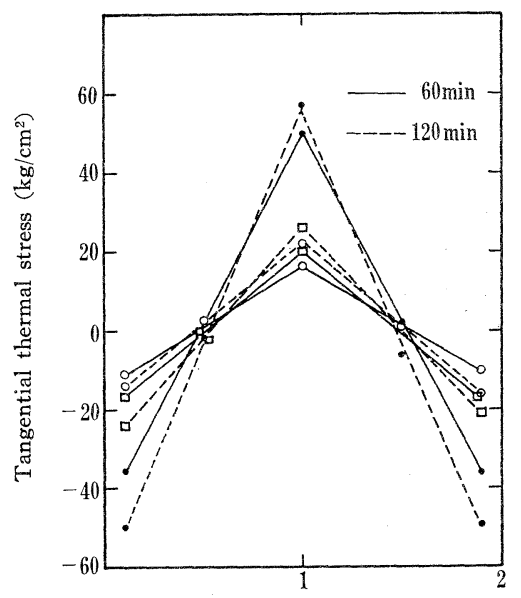

Distance from outer in $\mathrm{cm}$

- Chamotte, $\bigcirc$ Semi-SiC, $\square$ Cordierite

Fig. 6. The variation of tangential thermal stress in the side of sagger bodys with time when heated.

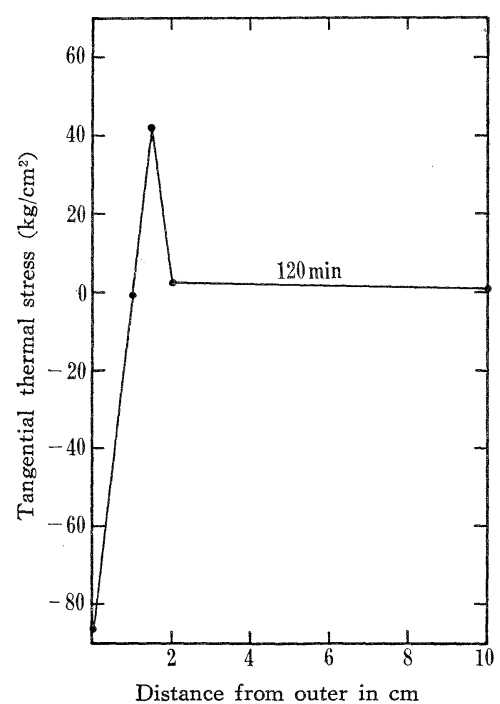

Fig. 7. The variation of tangential thermal stress in the base of chamotte body with time when heated.
れ以後は熱閒塑性域に入り，熱応力を生じないとすれば $4^{\circ} \sim 8^{\circ} \mathrm{C} / \mathrm{min}$ の昇温速度でもよいであろう。

\section{2 冷却時における熱応力}

予熱帯と同様にさやを側壁と底の部分とに分け，致の 最高温度を $1440^{\circ} \mathrm{C}$, 冷却速度を $4^{\circ} \mathrm{C} / \mathrm{min}$ としたときの さやに発生する応力分布を図-8 と 9 亿示す.

半炭化珪素質さや，コーディエライト質さやの側壁 は，引張応力に関しては比較的急冷をおこなってもひび 割れをしないが熱閒塑性限界の $600^{\circ} \mathrm{C}$ 以下で圧縮強さ の限界を $200 \mathrm{~kg} / \mathrm{cm}^{2}$ とすれば $6^{\circ} \mathrm{C} / \mathrm{min}$ の冷却速度が

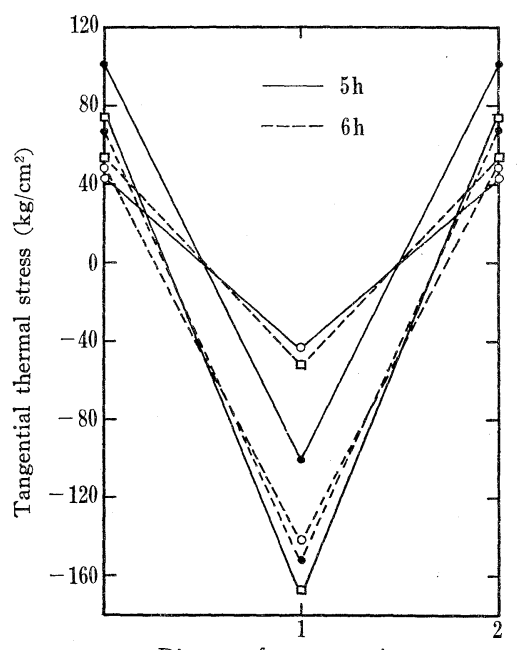

Distance from outer in $\mathrm{cm}$

- Chamotte, $\bigcirc$ Semi-SiC, $\square$ Cordierite

Fig. 8. The variation of tangential thermal stress in the side of sagger bodys with time when cooled.

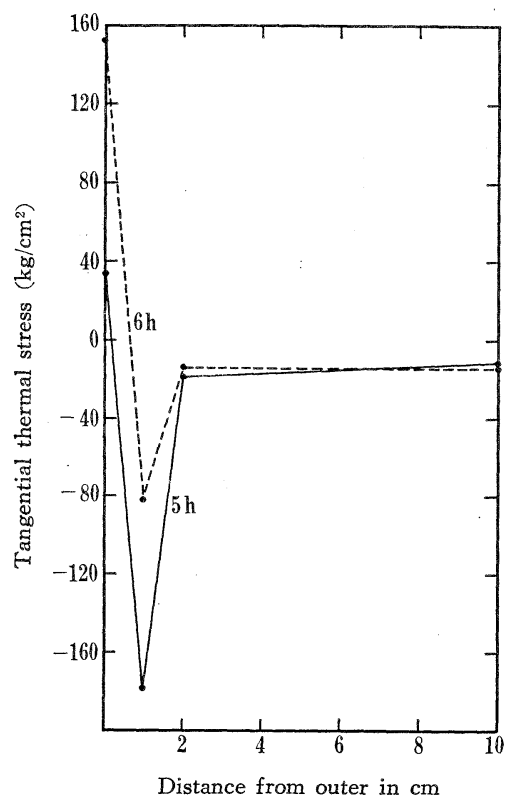

Fig. 9. The variation of tangential thermal stress in the base of chamotte sagger body with time when cooled. 
限界であろう。また, シャモット質ではさやの表面温度 が $240^{\circ} \mathrm{C}$ 附近で引張応力が $100 \mathrm{~kg} / \mathrm{cm}^{2}$ となり，表 -2 と比較して破壊の恐れがある. 従来, 冷却帯の温度降下 速度は $600^{\circ} \sim 480^{\circ} \mathrm{C}$ 間では, できるだけゆっくり下げ たほうがよいと言われているのは, 被焼成素地中の混入 不純物としての石英の存在による異常膨脹もさることな がら, 熱間塑性限界がこの上限附近にあり, さやが弾性 体領域に大る際, その変移速度に比例して内部ひずみ (永久ひずみ) を発生 ${ }^{10)}$ ， これが加成されるためでは ないかと思われる。また, この温度附近は泠却空気の接 触による温度差もでき易い。

底円板部の熱応力は, 図からシャモット質では引張り 応力が極めて大きい.この引張り応力洞じ条件のもと に抢ける側壁に発生した応力よりも大きいために, この ものの刍裂は底の縁の切線に対して垂直に半径方向に進 行することが推定される. 半炭化珪素質, コーディエラ イト質さやでは, 亀裂の発生は側壁, 底の何れも同じ程 度の条件で発生すると思われるが, 強いて言えば, やや 側壁部で起こり易いのではなかららか。

以上の結果から推定して, それぞれのさやの安全使用 条件はシャモッ卜質 $1.5^{\circ} \mathrm{C} / \mathrm{min}$, 半炭化珪素質, コーデ ィエライトは $6^{\circ} \mathrm{C} / \mathrm{min}$ の範囲内の弿の加熱, 冷却速度 であろう。

実際に, コーディエライト質, 半炭化珪素質の $30 \mathrm{~cm}$ 食㿼用さやをそれぞれ 20 個あて試作して前述の図-2 に示した条件でのトンネル塞を利用して 70 回までの耐 用状況を調べた結果, その破損はそれぞれ 5 個と 3 個で あり,また, シャモット質では, 僅かに 6 個が 5 回以上 の使用に耐えた。

\section{7. 総括}

トンネル窯で使用するさやの耐久性向上を目的として 半炭化珪素, コーディエライト質さや素地の物理性質を 測定した。かつここれらのさやがトンネル梥内で使用さ
れたときに，さや素地に生ずる温度勾配と熱応力とを計 算によって求め, $30 \mathrm{~cm}$ 径の大きさのそれぞれのさやの 安全な使用条件はシャモッ卜質 $1.5^{\circ} \mathrm{C} / \mathrm{min}$, 半炭化珪素 質とコーディエライト質は, ともに $6^{\circ} \mathrm{C} / \mathrm{min}$ の昇温, 冷却速度が限界であることを推定した。

\section{文献}

1）佐々木茂式, 窯協 68 [11] 255-67 (1960); S.S. Manson, W. Smith, J. Am. Ceram. Soc. 38 [1] 18-27 (1955).

W.D. Kingry, J. Am. Ceram. Soc. 38 [1] 3-14 (1955).

原隆治, 鉄と鋼. 49 [11] 1669-1675（1963）など.

2）鈴木弘茂, 案協 72 [11-2] C 813 (1964).

3）高津 学, 高見昭雄, 案協 75 [11] 315 (1967).

4) 稲垣甲子郎, 材料試験 10 [93] 451 (1961). 稲垣甲子郎，材料試験 10 [95] 617 (1961). 稲垣甲子郎, 材料試験 11 [103] 253 (1961). 稲垣甲子郎, 鳥居高夫, 窵協 73 [1] 9 (1965).

5）稲垣甲子郎, 窯協 66 [12] 305 (1958). 稲坦甲子郎, 材料試験 10 [97] 753 (1961). 稻垣甲子郎, 材料試験 10 [93] 451 (1961); 窯協編, 窯工ハンドブック， p. 1313, p. 1340 (1966) (技報堂).

6) 小平吉男, “物理数学”, Vol. 2, p. 322 (1952), 岩波書 店. 川下研介, “熱伝導論”, p. 65 (1966), オ一ム社.

7) 化工協編, “化学工学便覧”, p. 178 (1964), 丸善.

8) B.A. Boly, J.H. Weiner, "Theory of thermal stress", John Wiley \& Sons (1960).

S. Timoshenko, T.N. Goodier, "Theory of elasticity 2nd Ed." p. 401 (1951).

9) A.L. Roberts, Trans. Brit. Ceram. Soc. 36, 326 (1937).

M.C. Booze, S.M. Phelps, J. Am. Ceram. Soc. 8, 361 (1925).

K. Eendell, Ber. Deut. Keram. Ges. 14, 16 (1933). D.A. McGraw, J. Am. Ceram. Soc. 35 [1] 22 (1952).

10）渡辺正紀，佐藤邦彦，造船協会論文集 86 [3] 185 (1954).

渡辺正紀，佐藤邦彦，造船協会論文集 88 [9] 155 (1955).

渡辺正紀，造船協会論文集 86 [3] 173 (1954)。

(7/30/1968 受付) 